\title{
Justification of specific principles of state and public management for sports area development in Ukraine
}

\author{
Authors' Contribution: \\ A Study Design \\ B Data Collection \\ C Statistical Analysis \\ D Data Interpretation \\ E Manuscript Preparation \\ $\mathbf{F}$ Literature Search \\ G Funds Collection \\ Volodymyr Prikhodko ${ }^{1 \text { ABDEF, Oleksandr Tomenko }}{ }^{2}$ ACBF, Paweł Radziejowski ${ }^{3}$ DEF, \\ Nina Dolbysheva ${ }^{1}$ ABDEF , Dmytro Solovey ${ }^{1}$ BEF, Yaroslav Galan 4 DEF \\ ${ }^{1}$ Prydneprovsk State Academy of Physical Culture and Sports, Dnipro, Ukraine \\ 2 Sumy State A.S. Makarenko Pedagogical University, Sumy, Ukraine \\ ${ }^{3}$ Czestochowa University of Technology, Czestochowa, Poland \\ ${ }^{4}$ Yuriy Fedkovych Chernivtsi National University, Chernivtsi, Ukraine
}

abstract

Background: The paper deals with the problem of sports area management improvement. The aim of the study is to substantiate the specific principles of state and public management, the application of which should be developed and implemented in the State Strategy of Ukraine in relation to high performance sports as a way of realization of the state policy.

Material and methods

Literature analysis, analysis of materials from the Internet, content analysis, generalization and analogy, expert evaluation and coefficient of Kendall's concordance.

Results: The findings of content analysis of the Sports and Physical Activity of Ukraine until 2032 Development Strategy, which is used to justify the system of state and public management principles for the development of the sports sphere in Ukraine, are highlighted. The quality of the management principles system has been verified by using an expert evaluation (coefficient of Kendall's concordance -0.82).

Conclusions: Content analysis has specified the requirements for the content of the Sports and Physical Activity of Ukraine till 2032 Development Strategy. The system of principles is logically constituted by strategic, tactical and operational principles.

Key words: management principles, development strategy, reform, physical culture, sports.

\section{article details}

Article statistics:

Full-text PDF:

Received: February 2021; Accepted: December 2021; Published: December 2021

Copyright

Indexation:

(c) Gdansk University of Physical Education and Sport, Poland

Celdes, Clarivate Analytics Emerging Sources Citation Index (ESCI), CNKI Scholar (China National Knowledge Infrastructure), CNPIEC, DOA), EBSCO - Central \& Eastern European Academic Source, EBSCO - SPORTDiscus, EBSCO Discovery Service, Google Scholar, Index Copernicus, J-Gate, Naviga (Softweco, Primo Central (ExLibris), ProQuest - Family Health, ProQuest - Health \& Medical Complete, ProQuest - Illustrata: Health Sciences, ProQuest Nursing \& Allied Health Source, Summon (Serials Solutions/ProQuest, TDOne (TDNet), Ulrich's Periodicals Directory/ ulrichsweb, WorldCat (OCLC)

Funding: This research received no specific grant from any funding agency in the public, commercial, or not-for-profit sectors.

Conflict of interests: Corresponding author: Open Access License: Authors have declared that no competing interest exists.

Yaroslav Galan; Yuriy Fedkovych Chernivtsi National University, Chernivtsi, Ukraine y.galan@chnu.edu.uae-mail This is an open access article distributed under the terms of the Creative Commons Attribution-Non-Commercial-NoDerivatives 4.0 International (https://creativecommons.org/licenses/by-nc-nd/4.0/), which permits use, distribution, and reproduction in any medium, provided the original work is properly cited, the use is non-commercial and is otherwise in compliance with the license. 


\section{INTRODUCTION}

In addressing the issue of justifying the state and public management (SPM) principles system by the sports sector development, the strategic decisions made earlier in the area of sports shall be considered. To start with, the Decree of the President of Ukraine "On the preparation and participation of Ukraine athletes in the Olympic, Paralympic, World Games on non-Olympic sports, Global and European Championships" [1, 2] must be reviewed. The fact that although this document was adopted in 2005, it is noteworthy that its content was amended in accordance with Presidential Decree No. 517/2009 dd. July 8, 2009 and No. $174 / 2017$ dd. July 4, 2017, i.e., it may well be considered long-term and valid. Therefore, the provisions made it over the long term would obviously have to be fulfilled. Instead, several primary causes prevent the set essential steps from being implemented.

The first one is a lack of specificity and a declarative nature of the content, resulting in impossibility to define certain actions, terms and executors, examples being the provisions of the Decree: "to promote the attraction of extrabudgetary funds in line with the effective procedure", "to facilitate the development and effective functioning of the training system for athletes of higher qualification and the Olympic reserve", "to implement measures for improvement of the system for scientific, methodological, medical and biological support of the Ukraine national team".

The second one is that the proper provision of a sports reserve preparation qualitative process is viewed somehow superficially, as a minor matter without even mentioning the need to create modern local sports facilities. It is evident that the importance of the abovementioned Decree in SPM improvement by the sports field would be insufficient.

Another significant Decree of the President of Ukraine was entitled "On the National Action Plan for the Implementation of State Policy in the Field of Physical Culture and Sports" [3]. Its content review acknowledges the availability of all the disadvantages already mentioned therein. Among the concepts stated in this Decree, but not fulfilled, were: "to tackle the issue of applying efficient mechanisms for financing programs of mass sports and high performance sports development including through attracting share of the profits gained by domestic producers of alcohol and tobacco products, gambling", "to provide, while drafting the bills on state regulation of activities for the issue and holding of lotteries and cash draws, a solution to the issue on additional payments from such activities for physical culture and sports development", etc.

Similarly, declarative intent and a perfectly natural outcome failure to execute the set plans relate to other important documents concerning the state regulation of the sport sphere: "On approval of the strategy formation for the Olympic training modern system for the period till 2020" [4], "On approval of the state targeted social program for the development of physical culture and sports for the period till 2020" [5], "Strategy for the formation of an Olympic training modern system for the period till 2020" [1].

Equal in terms of content and unviable in the area of sports should be considered a significant in scope resolution of the Verkhovna Rada of Ukraine "On ensuring sustainable development of the sphere of physical culture and sports in the conditions of decentralization of power" [6]. An examination of its implementation shows that, as a whole, the right set questions related to the sports development failed to have been completed, and therefore, no impetus has been given to the development of sports in the context of decentralization.

All of the above, unfortunately, also affects the Law of Ukraine "On Physical Culture and Sports", adopted in 1993 with the subsequent amendments [7]. 
Thus, the unsatisfactory state of preparation and implementation of legislation on sports development management indicates that there is a scientific problem, since it does not ensure a significant improvement in the state of the field.

In view of the above, the aim of the study is the justification of the system of specific, inherent in the field of sports principles of state and public management by its development, applying of which the Ukraine state strategy related to high performance sports as the way of state policy realization should be developed and implemented.

\section{THEORETICAL BASIS AND PRECONDITIONS OF STATE AND PUBLIC MANAGEMENT SPECIFIC PRINCIPLES FOR SPORTS AREA DEVELOPMENT JUSTIFICATION}

Theoretical methods, such as literature analysis, analysis of materials from the Internet, content analysis as well as generalization and analogy were used to distinguish the problem, to determine the degree of the relevance of issues that were solved in the course of the study, to theoretically justify the purpose of study, and to work out a system of specific principles for state and public management of sports development in Ukraine.

A review of the literature [8-12] was conducted according to the best scientific sources. The quality of the articles was evaluated based on a set of criteria for the use of systematic review methods to examine views [13] and other recommendations [14]. The initial search included 62 articles; the final list comprises 38 sources.

The content analysis in accordance with recommendations of Pastukhov [15] and Kharchenko [16] was used to study the Sports and Physical Activity of Ukraine until 2032 Development Strategy and other documents.

Recently, the Ministry of Youth and Sports of Ukraine has made public "Strategy for the Development of Sports and Physical Activity of Ukraine until 2032" (hereinafter the Strategy). Its peculiarity, according to one of the authors, is that it covers a period of 12 years that spans three cycles of the Summer Olympics. But the experience of preparing a perspective and valid document, designed for three Olympic cycles at a time, is missing in Ukraine. A reading of the document in the context of assessment of the existing ones proves that a profound analysis and substantial elaboration of the Strategy, which must be fulfilled before its implementation, is an absolute requirement in determining further development of sports. Therefore, there is an urgent need in:

- justification and evidence of the viewpoint of the Strategy authors who are responsible project developers;

- reliability of the analysis outcomes and determining the Strategy adequacy by practical implementation;

- elaboration, if applicable, of the Strategy content in accordance with the proposed system of principles.

Because the Strategy is generated and accepted in the society, it aims to provide quality, positive changes in the sports system. The management principles imply basic concepts, patterns and rules of conduct for managers while carrying out their managerial functions. Therefore, it is obvious that the definition of management principles belongs to the area of theoretical developments, the latter being the result of the scientists' awareness of the essence of the phenomenon of humanitarian sphere governance. Based on the above, it is vital to distinguish, firstly, the general principles, i.e., those which are compulsory also in sports, and secondly, the principles specific to the field, or complementary to universal ones which are mandatory in the field of public life. 
Unlike sports, the topic of state and public administration in its adjacent education area has been thoroughly elaborated. Thus, the principles of governance that can be classified as general are defined here: human and citizen's rights and freedoms priority; the rule of law; mutual respect and partnership; representativeness of public authorities, public associations and other social institutions and the capacity of their representatives; obligation to review parties' proposals; priority for conciliation procedures; transparency, openness and publicity; obligation to comply with the agreements reached; mutual responsibility of the parties [17]. Similarly, we will accept as a postulate the assertion (the assumption which in a scientific theory is accepted without proof as a starting point) that we consider these stated principles in relation to state and public management of the sport area as general.

The essence of state and public sports management involves concerted interaction between the state and the community in addressing various issues related to the ability to responsibly and efficiently influence the sports policy, including through adoption and implementation of managerial decisions aimed at promoting sports development in the interests of the citizen and the state, and, as a result, to ensure a supportive social environment. Objective complexity of the state strategy development [18, 19, 20,21], faced by the authors of the Strategy [22], is that this significant document should combine socially crucial short-, medium- and long-term goals [23, 24], neither of which can be missed to compensate reaching a part of them.

Apparently, the short-term goals and objectives stem from the features of the current year, being both the year of training completion and participation of our leading athletes in the 21st Summer Olympic Games in Tokyo (Japan) and, certainly, the period of "rebooting" the state and public sports management system. Thus, the first Olympic cycle, which begins in 2021 and ends in 2025, should ensure a development of a modern system of athletes training, practice of high-quality public administration, establishment of training facilities, etc.

Therefore, there is an issue of primary, even prior to the adoption of the Strategy wording, definition of sports management system principles that take into account necessity and ensure unconditional achievement of the goals of its further progress.

Goals, in line with the importance and duration for the entity to be managed, are divided into strategic (long-term), tactical (medium-term) and operational (short-term). While goalsetting the desired state of the controlled object that the subject seeks to achieve may be extensively detailed and presented with varying degrees of accuracy, depending on the controlled object desired state nature and detail description in the managers' perceptions, the impact goals can be divided into trajectory ones and spot ones. Trajectory goals determine the change direction in the state of a managed object and by nature can be mutually neutral, cooperating or competing, whereas spot goals are shaped by the subject as seeking to achieve a specific outcome [25].

The managerial influences crucial to reach mutually neutral goals do not intersect and are independent of one another. In the case of the cooperative relations goals, the managerial impacts are vital for their realization and complementing one another, so that one of them also contributes to the application of the other. Frequently, reaching one of the goals ensures realization of the other, cooperation with it. It is only when the cooperative goals are met that a synergistic effect can be gained. In the case of competing goals, achieving one will mean abandoning the other. This takes place, for instance, when goals might be met utilizing the same limited resource, i.e., at the expense of the same amount of funding. In sports, the development of those kinds of sports that are currently identified as priorities are supported likewise [26]. 
The following main features of state and public management can be distinguished: joint management activities of state and non-state entities in the sports management; decisionmaking by the governmental body with the obligatory coordination of the provisional decision with public members; partial delegation of authorities to the bodies representing interests of certain public groups in local communities. Formulation of the development strategy is a part of a more general issue of implementing the state regulatory policy (SRP) in any field [27]. This complex and multidimensional process is often ineffective due to uncertainty of the principles chosen by the developers, the unidentified goals and means to reach them.

However, the Strategy analysis proves that the concept of decentralization of power has not been taken into account. In the section "On Strategy", among the five major vectors of public policy, in the part devoted to sport, we can merely find the following: "industry streamlining and horizontal ties strengthening". But such a restriction on the public policy content in the section "On Strategy" is irrelevant in the context of the terms of the existing sports development.

The present statement will not seem exaggerated in case if other identified vectors of the Strategy are analyzed:

- "qualitative changes in the high-performance sport" - has this been envisaged without decentralization?

- "development of sports infrastructure to comply with international standards"- has this as well?

Thus, all four of the five vectors concerning sports are not supposed to involve the regions as partners although the regions accumulate main funds and specialists.

But in order to proceed with this, the authors "On Strategy" section should be aware of the need to streamline the field of sports by improving both horizontal and vertical ties. It will also call for targeted action by both national sports federations and local authorities, for instance, in joint drafting of cooperation agreements between them, developing a much better qualitative rating to identify the best performing federations and areas for sports development, elaborating a new logic to hold national competitions by federations, some of which should be open to foreign athletes.

The development of sports in Ukraine in terms of decentralization of power already has a scientific basis $[28,29]$. Therefore, the explanation in "On the strategy" section that from September to November 2019, 18 focus groups and 3 strategic sessions were held with the Ministry of Culture, Youth and Sports of Ukraine together with more than 300 representatives of the sports community discussing area issues, ways to solve them and policy vectors for "Sport" is not convincing.

It is emphasized that "The strategy must be based on deep research and certain evidence, that is, it cannot be groundless... Achieving SRP strategic goals is only possible given the appropriate assessment of risks, costs or benefits, opportunities, quantitative and qualitative indicators of regulatory acts efficiency", etc. The major requirements for such evaluation activities are objectivity, economic feasibility, compliance with market requirements, involvement of experts in certain valuation steps, minimization of government expenditures on economic relations regulation. The proper assessment is intended to positively influence the speed and clarity of SRP implementation [30].

Generalizing scientific work related to strategic planning rules and considering the country legislation, it is feasible to elaborate a Strategy for sports development in accordance with the principles of strategic development planning for socio-economic macrosystems, as well as mesosystems - regions, microsystems - cities, districts and voluntary unions of regional communities. 
The developers of the Sports Development Strategy note: "Ukraine should have the concept for enhancing the level of physical activity, the quality of high-level athletes training, the improvement of the infrastructure and the sports industry for many years, taking into account interests of all segments of population, age categories, gender groups, social statuses, possessing exclusive approach and equal opportunities", although the concept itself is not presented.

The next section of the Strategy is entitled "The Purpose of Implementing the 2032 Strategy". Apparently, for the purpose to specify, "The Objective" was split by the authors to 15 items. Meanwhile, the analysis shows that the goal detailing only confirms inattention of the Strategy's developers to the support of scientists and the underestimation of the sports science role in justifying further ways of sports development in Ukraine and elaboration of innovative technologies for sports [31]. After all, the topic of the science contribution role in "Vision" is totally absent and, therefore, excluded from the benchmarks for further development of the sport area.

In addition, the way in which the goals in "Vision" are worded in terms of high-performance sports is declarative, which fails to give an idea of the Ukrainian athletes' expected success. In their style, the items meet the wishes, but not set outcomes both in the creation of sports development conditions and in the leading athletes' achievements in the most prestigious international competitions, such as the Olympic Games.

In the "Ecosystem First Stage Transformation Results" section of the Strategy, the items that cause the most concern relate to the determinative year, i.e., 2021. This year proves to be the end and the beginning of the Olympic cycle; that is, by 2021, proper legislative and the organizational prerequisites for the further development of Olympic sports of high performance must be generated. It may be put this way: content and operation outcomes of MCYS in 2021 as the single body defining sports public policy and bears responsibility for it, will determine success of sports development for the upcoming years till 2025.

Therefore, the 2021 Strategy, the content of which is continued to be explored, calls to:

1. complete the legislative processes aimed at creating the regulatory framework for building a European sports system in Ukraine;

2. initiate transition education programs and develop transition maps for key subjects.

Considering the first item, the Strategy does not specify what legislative processes need to be completed; perhaps it is a question of the Laws of Ukraine required for the sports development? Furthermore, what is meant by the "European Sports System"? When it comes to the most important issues, it is definitely sports funding. But in Europe, a system where the sports development is primarily supported by local authorities is widely used (Table 1).

Table 1. The correlation of financing for physical culture and sports of governmental levels in European countries [35]

\begin{tabular}{ccc}
\hline Country & State share, \% & Local authorities share, \% \\
\hline Germany & 2 & 98 \\
Great Britain & 5 & 95 \\
Switzerland & 8 & 92 \\
Finland & 15 & 85 \\
Denmark & 16 & 84 \\
France & 23 & 77 \\
Spain & 24 & 76 \\
Italy & 43 & 57 \\
\hline
\end{tabular}


Considering the second item, what educational programs are meant and who will ensure the implementation of "transitional educational programs?" And how is it expected to obtain sufficient, unfortunately, or missing or incomplete knowledge that needs to be transmitted and mastered by educational program participants?

Considering the third item, it is clear that proper realization of the first and second items will fully determine the application quality of "start of the first programs of the Strategy implementation" item. In case of failure of the first two items, the third one will undoubtedly fail. The next year when the attempt can be repeated is the change of the next summer Olympic cycle, which is to take place in 2025 [32].

The next section of the Strategy is entitled "Partnership principles". With regards to the high-performance sport, the following must be paid attention to:

- here for the first time though with no specifics the term "decentralization" is used with reference to local budgets for sports development. MCYS will pay particular attention to the transformation in local governments; however, there is no explanation as to the nature of transformations in this section [33];

- equally declarative is the thesis that MCYS undertakes strategic leadership and is ready to support the sports sector to help it succeed, which is the direct responsibility of the newly created Ministry.

By nature, the Strategy does not change anything qualitatively. It says, "Starting from 2021, the Ministry is fully transferring to managerial solutions based on data analysis, transparent allocation of funds and grants through the created MCYS IT platform, distinguishing and targeting assistance for sports that need financial support from the state and are popular" [34]. As shown, it is further foreseen to distribute funds from the center already being used by the Ministry, albeit utilizing an IT platform. However, the share of local budgets in the overall balance of sports funding is unclear in terms of when and to what areas funds are to be allocated via the IT platform.

And how is the following thesis to be interpreted: MCYS is open to cooperation with private sector and international partners interested in establishing horizontal ties both at the highest level of executive power as well as regional, district and city sports departments?" Regarding the first part: it implies that MCYS is not opposed to cooperation, that is, it does not arrange this cooperation, but simply does not resist it? Regarding the second one: MCYS does not develop approaches to establishing the determined productive relationships at the senior executive level with regional, district, city sports departments, but merely expresses its interest in contacts?

It is not comprehensible why the title of the Law of Ukraine "On Physical Culture and Sports" does not satisfy the authors and for what reason it is necessary to change "physical culture" to "physical activity". "Physical activity" is a concept close to "movement activity" and is apparently minor in scope compared to either "physical culture" or "physical education?"

Regarding the section "Vector of the state: qualitative changes in high performance sports", superficially, without revealing domestic high performance sports development issues, the fragment "Issues" is described. In fact, it summarizes failures of Ukrainian athletes in the most prestigious Olympic sports. The fact that "we do not conduct rating sports events in Ukraine that would affect a positive development of the country's economy and infrastructure" is a derivative of a lack of modern conditions for athletes' training. The agenda should primarily focus on creating a quality training facility. Secondly, the question about contemporary objects for prestigious competitions should be raised; otherwise, there is no one to compete [35]. 
The Strategy states that "constant misuse of budget resources leads to improper allocation of money and as a result - to insufficient funding of leading athletes representing Ukraine, but having less opportunity to progress than their rivals in competing countries where the industry has been reformed. "But we cannot find an answer as to why this is happening".

Hence, the content of the section "Transformation Goals until 2025" appears to be unjustified and incomplete. It is unclear in what way we will be able to create an "autonomous and viable sports ecosystem", in what way we will be able to "improve the quality of the country's medal gains in rating international starts", and why it is essential and what "an increase in the number of Class A international competitions in Ukraine" will do to us.

Unfortunately, the "Steps to Goals Achievement" also fails to answer the questions raised, merely multiplying their number. For instance, could "transition to individual provision of TOP athletes" be considered a new step? This is a traditional task, but not a step, i.e. a guideline of how to do it. Likewise, all other "steps" do not provide explanations for ways to solve certain development tasks. "Developing Ukrainian athletes as better people"- it remains unclear of how these actions will be defined and reliably supported in practice. Or "prioritizing certain kinds of sports and annual update of the list containing state order definition for each sport performance values" - does this imply that someone will prioritize sports every year and assign a government order to those?

The provisions of "KPIs" fragment do not appear to be justified by the demand of state and society or unexplained. At least the following: "Since 2020, all sports federations are independent entities". Indeed, this is an important benchmark though the Strategy does not disclose the ways to achieve it.

Equally alarming is the content of "State Priority" fragment, e.g.: "The state ... will annually identify popular sports and rating competitions to form a state medal order based on analysis of values and international reports". Such an approach is viable for plant growing, but it is not suitable for many years of athletic training.

\section{USTIFICATION OF SPECIFIC PRINCIPLES OF STATE AND PUBLIC MANAGEMENT FOR SPORTS AREA DEVELOPMENT IN UKRAINE}

There have already been concepts of reforming high performance sports in Ukraine, i.e. an innovative project "The modern system of Olympic athletes training in Ukraine" and the prototype of the program "Sports development by the federation in Ukraine" scientifically substantiated, coming from the provisions of decentralization. Based on the conducted research, scientific development and analysis of the Strategy, a system of SPM features aimed at further sports area development in Ukraine was proposed (Table 2).

It is worth noticing that objective laws governing sports training function regardless of the mind and will of people and their activities. These laws are learned by studying the forms of their manifestation in the training and competitive process. The learning is manifested by the ideas of professionals who undertake to interpret the forms of evolution of such a social phenomenon as sports generating initial provisions [36]. Thus, laws are directly applied in the athletes' training practice, but due to their subjectivity, the principles of management cannot be taken as a direct consequence of objective laws.

The law usually means stable, repetitive connections and relations between phenomena determining objective conditions of existence and the development of a certain phenomenon. Discovering laws and formulating principles is done as a deliberate purposeful activity. Thus, guiding principles are a manifestation of objective laws in the subjective pattern of public consciousness, and thus reflect laws and relations of subjects in the course of sports training. 
Table 2. Specific principles of state and public management for sports area development in Ukraine (in the sports reform view)

\begin{tabular}{ll}
\multicolumn{1}{c}{ Principles group } & \multicolumn{1}{c}{ Principle title } \\
\hline 1. Strategic & $\begin{array}{l}\text { 1.1. Streamlining sports system by } \\
\text { improving its horizontal and vertical ties }\end{array}$ \\
& $\begin{array}{l}\text { 1.2. Arrangement of scientific, } \\
\text { methodological and technological } \\
\text { prerequisites of sustainable development of } \\
\text { the sports field }\end{array}$
\end{tabular}

1.3. Provision of prerequisites for personnel availability to ensure sustainable development of sports

1.4. Ensuring involvement of all kinds of local resources to promote the sports development

1.5. Compliance of sports organizations' strategies with available resources and technologies

1.6. Systematic influences and controllability

2.Tactical 2.1. Establishment of an effective state body for sports management

2.2. Elaboration of sports development models by federations

2.3. Consideration and approval of external and internal sports development factors by federations

2.4. Founding of viable interaction in the system "state - federation - area"

3. Operational 3.1. Development of systems for reliable professionals to reform the field of sports

3.2. Development tools for macropedagogical influence on changes in the expertise of athletes training

3.3. Legitimacy (consensus) with sports professionals

Principle content

Continuous improvement and utilization of a set of features of the current state of the sports socio-economic system via assessment of its functioning, achieved results and forecasted sports system development tendencies

Identification of priority areas for scientific and methodological support as well as technological development based on the extensive analysis of the current situation and interdependence between global, national and local issues of sports development including through determination of competitive advantages of domestic sports

Outlining of 5-7 priority areas that should be focused on while on allocating resources to achieve the strategic goal of both staffing and social development of the sports system

Identification of priority areas for attracting resources in regions, cities and united territorial communities. Associating public and private partnerships in sports development

Determination of strategic action plan for local authorities, federations and sports organizations to ensure priority sports development in line with the availability of necessary and various resources, including the technologies needed for athletes training

Integrated solution of solely sports, as well as related economic, social and environmental problems. Availability of criteria for evaluating of sports development strategy success

Development and implementation of sports development strategy being an outcome of scientific research taking into account domestic and foreign experience in accordance with a defined transparent methodology and generated effective tools of sport area state management

Ability to see prospects for sports development by the professionals working in this area. Creating conditions for rapid and well-grounded content adjustment of sports development tactics

Possibility of reasonable intervention (correction) of the set plans for impact on individual organizations and the athletes' training process considering the dynamic state of external and internal factors for the development of modern sports

Mutual coherence of a legislative, regulatory program and forward-looking documents and managerial influences on concerted action in the system of sports development at macro, meso and micro levels

Ensuring scientific and transparent processes of elaboration and implementation of the sports development strategy in the expert environment along with broad coverage of intermediate results of implementation

Possibility of an effective impact on the condition of the whole sport area by advance interpretation and subsequent transparent use of legislatively and normatively determined, timely and efficient measures of state and public management

Perception of a strategic vision and an action plan by the majority of society, representatives of sports and political forces. Study and consideration of views of the professional community while approving the strategy by involving all concerned in the process 
Identification and grounding of management principles must meet a number of requirements: 1) view of the major, objectively necessary manifestations of management; 2) reference to stable ties and relations; 3) coverage of ties and relations inherent in governance as an integral phenomenon; 4) display of features and differences of management depending on the area they are justified in.

It should be emphasized that the sports training process is long-lasting, so it combines the solution of strategic, tactical and operational objectives to be met by the management principles system.

Finally, we need to consider that the principle is not the cognition starting point, but its natural outcome. Therefore, the principles may and should change if the set goal, in the opinion of the controlled entity, has been achieved.

In order to evaluate the SPM principles, an expert survey was conducted among 23 people of the teaching staff at the Sports Departments of the Prydneprovsk State Academy of Physical Culture and Sports, Sumy State A.S. Makarenko Pedagogical University, Sumy State University, 9 of which are Honored Trainers of Ukraine, others - PhD with at least a decade experience in higher education institutions. The author's questionnaire was used to assess the Kendall concordance coefficient. According to the survey results, the coefficient

of Kendall's concordance, namely 0.82, indicates that the expert's opinions regarding the system quality are steady, which consequently proves a high degree of consistency and reliability of the survey findings.

\section{DISCUSSION}

Over the past decades, rivalry of leading athletes and teams at the most prestigious international competitions has intensified. In order to ensure that success of Ukrainian athletes in these representative competitions is sustainable, rather than accidental in nature, and to promote its tendency for stable growth, it is crucial to assure the existing athletes training system upgrade through an implementation of quite a delayed reform which should aim to overcome consequences of administrative and command management during the USSR times. It goes without saying that this can be achieved through better state and public management of the whole sports field.

One of the essential mechanisms of effective management is long-term planning based on the Strategy. In order to fulfill the function of an influential tool, such Strategy must be of high quality, relying on both general theoretical provisions and statutory requirements for creation of similar state documents, as well as on findings of the scientists who have focused their efforts in the sport area.

Therefore, the Strategy authors should, among other things, rely on the elaborated system of SPA specific principles with the development of sports in Ukraine, which was justified in the present study.

The system of SPM principles with the development of the sport areas associates three groups of principles. Each of the group is not self-sufficient; on the contrary, one of the groups of principles underpins others, which proves that together they shape the coherent system. Establishment of principles for the three groups mentioned above, firstly, complies with the initial provisions of long-term planning and, secondly, quite naturally for the longterm planning corresponds to the development of modern sports. 
Thus, the principle of "Providing scientific, methodological and technological prerequisites for the sport area sustainable development" is included in the strategic group. It stipulates that the governing body of the sports sector being a relevant ministry requires some action to make the principle work.

The same applies to the principle of "Provision of personnel preconditions for the sports sustainable development" where without the organizational work of the corresponding ministry, training of quality sports managers, sports doctors and sports psychologists along with other strategic principles the preparation activity will not start.

The abovesaid can be transferred to the tactical group on the basis of the principle "Creating an effective body of state sports management". Apparently, it is not a matter of deciding on the establishment of the Ministry of Youth and Sports of Ukraine, but rather of making such efforts after its foundation that would facilitate its efficient activity. This shift of emphasis is reflected through the operational principle of "Developing a system of consumer knowledge required for sports reform", including through a team of expert's involvement aiming to advise management and prepare documents.

The same applies to the operational principles, for instance "Development of tools for macro-pedagogical influence on changes in athletes training practice" [37]. However, no adherence to the strategic principle of "Streamlining the sports system by improving its horizontal and vertical ties" can be spoken about unless, in 2020, for example, there is an improved content of the ranking determining sports achievements of the regions. Currently, the rating calculation spreads from children to adult athletes for positions 1 to 12 occupied at championships and cup competitions in Ukraine and abroad [38, 39]. But this does not in any way encourage the federations and local authorities to win medals, while winning medals and nothing else is taken into account at the Olympic Games. Therefore, it is the medals that should stipulate the sports development. Therefore, it would have been necessary to announce already in 2020 that starting from 2023, i.e., prior to the next Olympic Games in Paris (France), the rating will undergo significant alteration. Namely, that will be clarified from now on: only positions from 1 to 3 will be taken into account in adult athletes' competitions. This will mean that a region with a modest economic potential focusing on the development of one or two Olympic sports will be able to outstrip a more powerful but "awkward" region. This is exactly how regional authorities can be influenced to identify sports in the fall of 2021 - summer 2025 and to support their development providing the full range of needed resources.

The authors forecast that the elaborated system of SPM specific principles with the progression of sport area will be further improved, since its refinement will be facilitated by accumulation of experience related to developing and implementing the existing longterm sports management document in Ukraine. Meanwhile, this system already provides sufficient opportunities to develop a better "Strategy for the development of sports and physical activity of Ukraine till 2032".

\section{CONCLUSIONS}

The conducted content analysis, as defined in the purpose of the research, specified the requirements for the content of "Strategy for the development of sports and physical activity of Ukraine till 2032", actualized the development and application of an SPM specific principles system in the field of sports. Created with their use, the Strategy will express a clear vision of the public policy aimed at positive and inevitable changes in the domestic sports sector. 
There are three groups of principles, namely strategic, tactical and operational, that make a sound system of SPM principles in the sport area development. Together they shape a system of interrelated requirements and benchmarks which will contribute to the consistent and efficient development of sport.

Thus, the abovementioned implies clarification of content of the existing "Strategy for the Development of Sports and Physical Activity of Ukraine till 2032" requiring significant refinement to be reached by a more explicit justification and presentation of a certain sequence of steps by both specialists of the Ministry of Youth and Sports of Ukraine and regional national federations and sports government officials that will ensure the highperformance sport transition to its new quality. The evidence of the reform maturity should lie in aligning our athletes' training content and conditions with the world and, above all, European practices.

\section{REFERENCES}

[1] Cabinet of Ministers of Ukraine. Strategy for the formation of a modern system of Olympic training for the period up to 2020. [Disposal of the Cabinet of Ministers of Ukraine; No 592-p; 2009.06.03]. Retrieved from: https://www.kmu.gov. ua/npas/220366473

[2] Legislation Ukraine. On the preparation and participation of athletes of Ukraine in the Olympic, Paralympic and Deaflympic Games, World Games on non-Olympic sports, World Martial Arts, World Universiades, World Championships and Europe. [Decree of the President of Ukraine; No 1113/2005; 2005.07. 19] Retrieved from: https://zakon.rada.gov. ua/laws/show/1113/2005

[3] Legislation Ukraine. About the National Action Plan for the Implementation of State Policy in the Field of Physical Culture and Sports. [Decree of the President of Ukraine; No 667/2006; 2006.08.02]. Retrieved from: https://zakon.rada.gov.ua/ laws/show/667/2006

[4] Legislation Ukraine. On approval of the Strategy for the formation of a modern Olympic training system for the period up to 2020. [Decree of the Cabinet of Ministers of Ukraine; No 592-r; 2009.06.03].

[5] Legislation Ukraine. On approval of the State Targeted Social Program for the Development of Physical Culture and Sports for the Period up to 2020. [Resolution of the Cabinet of Ministers of Ukraine; No 115; 2017.03.01]. Retrieved from: https://zakon.rada.gov.ua/laws/show/592-2009-\%D1\%80

[6] Legislation Ukraine. On Ensuring Sustainable Development of Physical Culture and Sports in the Decentralization of Power. [Resolution of the Verkhovna Rada of Ukraine; No 1695; 2016.10.19]. Retrieved from: https://zakon.rada.gov.ua/ laws/show/1695-19

[7] Law of Ukraine “On Physical Culture and Sports”. [Resolution of the Verkhovna Rada of Ukraine; No 3808-XII; 1993.12.24] Retrieved from: https://zakon.rada.gov.ua/laws/show/3808-12

[8] Beskorovaynaya VA. State regulation of the sphere of physical education and sports services (methodological and organizational-economic basis). Abstract Dokt. Diss. St. Petersburg; 2008. Russian.

[9] Bliznevsky AYu. Program-target management of the development of the sphere of physical culture and sports in the space of the Krasnoyarsk Territory. Dokt. Diss. Krasnoyarsk; 2015. Russian.

[10] Gasuk IL. Public administration of physical culture and sports: state and prospects of development. Kharkiv; 2011 Ukrainian.

[11] Hatsulya O. Development of sectoral management in the field of physical culture and sports: conceptual principles. Public administration and local self-government, 2015;1(24):176-185. Ukrainian.

[12] Zhurba MA. Foreign experience of state regulation of the sphere of physical culture and sports. Actual problems of the state and law. 2017;51-57.

[13] Harden A. Applying systematic review methods to studies of people's views: an example from public health research. J Epidemiol Commun Health. 2004;58:794-800. https://doi.org/10.1136/jech.2003.014829

[14] Popay J, Roberts H, Sowden A, et al. Guidance on the Conduct of Narrative Synthesis in Systematic Reviews. A Product from the ESRC Methods Programme. Swindon: Economic and Social Research Council; 2006.

[15] Pastukhov AG. Content analysis of media text: new in method definition (book review: Rössler Patrick. Inhaltsanalyse. 2, überarb. Aufl. - Stuttgart; 2010. Russian.

[16] Kharchenko KV. Computer Content Analysis of Text Information; 2020. Retrieved from: http://leveltar.narod.ru/cta/teor. html Russian.

[17] Law of Ukraine "On education". Public self-government and public administration in the field of education. [Verkhovna Rada Bulletin; 2017; No 38-39, Art. 380]. Retrieved from: https://законодавство.com/zakon-ukrajiny/stattya-gromadskesamovryaduvannya-derjavno-325814.html

[18] Legislation Ukraine. About the Strategy of the state personnel policy for 2012-2020: [Decree of the President of Ukraine; No 45/2012. 2012.02.01]. Retrieved from: https://zakon.rada.gov.ua/laws/show/45/2012

[19] [Legislation Ukraine. On the National Security Strategy of Ukraine [Decree of the President of Ukraine; No 287/2015; 2015.05.26]. Retrieved from: https://zakon.rada.gov.ua/laws/show/n0008525-15

[20] Legislation Ukraine. On the Strategy for the Development of the State Youth Policy for the Period up to 2020. [Decree of the President of Ukraine; No 532/2013; 2013.09.27]. Retrieved from: https://zakon.rada.gov.ua/laws/show/532/2013 
[21] Legislation Ukraine. Olympic sports regulations in Ukraine. Order of the Ministry of Youth and Sports of Ukraine; 2013 No. 677; 2013.10.21. Retrieved from: http://search.ligazakon.ua/__doc2.nsf/link1/RE24425.html

[22] Ministry of Culture, Youth and Sports of Ukraine. (2019). Strategy of development of sports and physical activity of Ukraine till 2032. (2020, February 05). Retrieved from: https://drive.google.com/file/d/1TJ4JDgLSvQAFN8yC9CUoMMx FUmzTn11-/view?fbclid=IwAR1FXVVOM7VeerPfpA1qjpWaY1-xBZPh2QuIdiO2OQtGs8A4fpXILr4fKFo

[23] Kozlyuk E, Sait-Ametov, M. How to organize the strategic planning process. Practical recommendations for Ukrainian cities and districts. Simferopol; 2013. Ukrainian

[24] Zaitsev LG, Sokolova MI. Strategic Management. Rules and procedures for developing strategies Characteristics of strategies; 2002 (2019, December 20). Retrieved from: https://lib.sale/strategicheskiy-menedjment-knigi/pravilaprotseduryi-razrabotki-strategiy-63910.html Russian.

[25] Garkusha NM, Tsukanova OV, Goroshanskaya OO. Models and Decision Making Methods in Analysis and Audit. 2nd ed., Kyiv; 2012. Ukrainian.

[26] Prikhodko VV, Tomenko OA, Mykhailychenko OV. Improvement of the organization and content of scientific researches on physical culture and sports in Ukraine as an important prerequisite for their reform. Pedahohichni nauky: teoriia, istoriia, innovatsiini tekhnolohii. 2016;3(57):419-429. Ukrainian.

[27] Maliga V. Strategy as the basis for the implementation of sovereign regulatory policy. Visnyk Lvivskoho universytetu. Seriia yurydychna. 2015;61:30-36. Ukrainian.

[28] Prikhodko V, Seymuk A. A prototype of the activities of federations and territorial authorities on reforming the system of training athletes. Sportyvnyi visnyk Prydniprovia. 2019;3:36-52. Ukrainian.

[29] Prikhodko, V.V. (2014). Macropedagogics as a mechanism for regulating the development of sports in new organizational and managerial conditions. Fizychne vykhovannia, sport i zdorovia liudyny: dosvid i suchasni tekhnolohi,17-24. Russian

[30] Smentina, N.V. (2013). Features of the methodology of strategic planning in the system of state management of socioeconomic development of territories. Visnyk SumDU. Ekonomika, 4, 67-80. Ukrainian.

[31] Palik M, Abdi K. The relationship between watching sport events and spectators' engagement in physical activities. Medical-Biological Problems of Physical Training and Sports. 2018;12:320-327.

[32] Prykhodko V, Tomenko O. Innovative Approach to the Strategic Management of the Olympic Sport Reform in Ukraine. Market Manag Innov. 2019;1:357-366.

[33] Rowe NF. Sporting capital: a theoretical and empirical analysis of sport participation determinants and its application to sports development policy and practice. Int J Sport Policy Politics. 2014;7(1):43-61. https://doi.org/10.1080/1940694 0.2014 .915228

[34] Pityn M, Briskin Y, Perederiy A, Galan Y, Tsyhykalo O, Popova I. Sport specialists' attitude to structure and contents of theoretical preparation in sport. J Phys Educ Sport. 2017;Suppl3:988-994.

[35] Prykhodko V. An algorithm for managing the activities of federations to reform the system of training athletes. Pedahohichni nauky: teoriia, istoriia, innovatsiini tekhnolohii. 2019;6:276-295. Ukrainian.

[36] Sazonets VI. Development of methodological approaches to the formation of a system for managing the development of Olympic sports in the region. Physical Education of Students. 2012;5:92-98. Russian.

[37] Prikhodko V, Akhmetov R, Tomenko O, Tabinska S. Use of sports rating as a tool of state management of sports development in Ukraine. Sportyvnyi visnyk Prydniprovia. 2019;1:53-63. Ukrainian.

[38] Prikhodko VV. The role of macro pedagogy in creating the concept of sports reform in modern Ukraine. Sportyvnyi visnyk Prydniprovia. 2014;1:179-181. Russian.

[39] Yessentayev, T.K. (2016). Political influence on sportsmen's training system in olympic sports. Pedagogics, Psychology, Medical-Biological Problems of Physical Training and Sports. 2016;1:19-23. http://dx.doi.org/10.15561/18189172.2016.0103

Cite this article as:

Prikhodko V, Tomenko O, Radziejowski P, Dolbysheva N, Solovey D, Galan Y.

Justification of specific principles of state and public management for sports area development in Ukraine

Balt J Health Phys Act. 2021;Suppl(2):109-121

doi: 10.29359/BJHPA.2021.Suppl.2.11 